\title{
On Being and Belonging: Transnational migration and its bearing on my identity and sense of belonging
}

\author{
Sanjana Ragudaran ${ }^{1}$
}

\begin{abstract}
Movement of people within or between countries has taken place for millennia. Migration is a common phenomenon, where migrant experiences are known to be vast and varied. Although migration has been studied globally, there is a need to document personal migrant experiences to understand their struggles in order to build inclusive communities. This narrative describes the author's transnational experiences and struggles in trying to grapple with her identity and sense of belonging.
\end{abstract}

Keywords: Migrant experiences; transnational; sense of belonging; identity

\section{Migration}

As of 2020, I am one of the 272 million international migrants living outside of their country of birth. According to the United Nations, international migration has been rapidly increasing since 2000 (World Migration Report 2020). Migration has been well researched from the perspective of various disciplines including economics, sociology, geography, anthropology, tourism studies, and social work. This recent increase in migration, coupled with the complex nature of this phenomenon suggests a value can be found in how migrants experience a sense of belonging. This article provides a narrative insight of a migrant's story.

In the Fall of 2017, as we began the routine of a new school year, I picked up a children's book "Where is home little pip?" (Wilson, 2008) to read to my little one. It is the story of a young penguin who gets lost one day while its parents are fishing at sea. While searching for home the little one meets a whale, and seagull amongst other animals and becomes distraught as their description of home, does not match what her parents have sung to her every night. Mom and dad find their little one eventually and sing that home is where the three of them are together. I have read this book to my son numerous times over the years, but never did it resonate with me until that night. It resurfaced many emotions around who I am, my identity, and the concept of belonging and home. Here is my story.

\section{Setting the stage - growing up}

I was born and raised in Singapore, a tiny yet mighty island on the world map. I grew up with stories about Ceylon (Sri Lanka), the land my ancestors came from. My maternal and paternal grandfathers left from the northeastern part of Ceylon in the 1930s in the hope of better economic opportunities. They returned to marry their brides and always maintained close ties

\footnotetext{
${ }^{1}$ Sanjana Ragudaran, Assistant Professor, School of Social Work, Monmouth University, 400 Cedar Avenue, West Long Branch, NJ 07764, United States. E-mail: sragudar@monmouth.edu
} 


\section{On Being and Belonging}

with their families through mail and remitting when they could, during this time. My brother and I grew up listening to culturally rich stories filled with value about our homeland and were reminded that we should never forget our identity: what it means to be a Ceylonese Tamil. These stories were vital for diasporic families such as ours as although we did not have the means to visit our homeland, it provided a sense of place and belonging when we were children (Chamberlin \& Leydesdorff, 2004). In order to distinguish ourselves from Tamils of Indian origin, my predecessors identified as Ceylonese Tamils and we continue this tradition today. The distinction was made very clear to me at an early age that I am a Ceylonese Tamil, and it is even noted in my identity card today. In accordance with narratives on diaspora, although the Ceylonese Tamil community in Singapore was small, their diaspora was rooted in local connectivity and well-maintained strong ties to the homeland to this day (Blunt, 2007; Faist, 2010). I am not part of the majority race in Singapore, but that did not make me a lesser person. We practiced our culture and religion with no fear and were proud of who we are. I learned to play instruments such as the piano, and the veena (Indian string instrument), learned Carnatic vocal, and Bharatanatyam. Yes, I am cultured and educated-truly raised in such a privileged environment. Another important aspect of my identity was that it was just as important to be connected to the arts, and religion as it was to do well in school. We were a middle-class family with very humble roots, where my parents worked long hours to provide for us but no doubt, we were raised with privilege.

Regardless, nobody can shelter you from the outside world and being an introvert in my early years did not help. I realized by middle school that my race was not considered superior. Biology taught me otherwise, but the power of structural discrimination stemming from colonization and beyond was just too great even in middle school. Singapore has always taken pride in being known as a culturally plural society, with policies in place to govern relations between ethnic groups (Noor \& Leong, 2013). Although racism and discrimination may be less rampant in culturally diverse communities, research indicates that it is still present (Berry, 1997 \& 2013; Tan, 2004). Growing up, I had numerous experiences that heightened my awareness of my difference as a minority. Furthermore, the brown kids always hung out together but even the brown kids knew that there was something different about me. The Ceylonese Tamil in me revealed itself in various ways such as the way I speak Tamil. They did not understand certain words and I would go home and ask Amma (mother), what was wrong with the way we speak Tamil. Decades later I realized that one needs to understand the history of the land you descended from. Sri Lanka was colonized by the Portuguese, the Dutch, and the British. Linguistic experts confirm that colonization resulted in an evolution of the native languages, in this case more around words used for trade and day to day living (Jayasuria, 1999). If only I knew at the age of 9 to let my Tamil teacher and friends know that I was not an alien speaking a different language. Reflecting on these experiences, I believe that I identified more with the land of my forefathers than I did with the land I grew up in.

By my teenage years, I longed to belong. My brother and I would often ask our parents when we would be able to visit Sri Lanka. Although we would take family pilgrimages to India, I felt that something was always missing. When it was finally safe to travel to Sri Lanka in the early 1990s, our long awaited, highly anticipated trip was a dream come true. Being able to speak Tamil without having someone point out that you speak differently was a nice change. Familiarity with the food, and religious practices among other things made it feel like a homecoming. Still there was something lacking during this trip; that sense of belonging that I had highly anticipated. It was unsafe to travel to the northeast during this time due to civil

\section{Border Crossing}


unrest. Not being able to see the land of my grandparents left a sense of yearning in me. Life would go on, but this burning desire was buried yet alive. Through my teen years I struggled with my sense of belonging and identity. I thought I had somewhat developed my identity as a Ceylonese Tamil by my late teens, but little did, I realize, how fragile it was.

\section{Blending in while studying in Australia}

Yes, I am absolutely guilty of trying to blend in. I am not ashamed to have tried to blend in especially when I went to study in Australia at the age of 16. Moving to a majority white country, I tried many ways to blend in, typically the accent, clothing, and even changing my way of thinking. However, it never felt right; like living out of my own skin. I looked at other students who were of Asian ethnicity, born and raised in Australia and how they tried so hard to blend in. Although I slowly realized over time that I could never ever blend in, it took time to process and be comfortable with this notion. To begin with my skin color was and still is a blatant reminder that I am not white! In doing so, I was not only being ashamed of my identity but also beginning to lose my sense of identity, the Ceylonese Tamil in me. I was trying to be someone I was not. Every morning I looked in the mirror and saw me; my brown skin, my features which were and continue to be a daily reminder today. Staying connected with family while away and spending the annual holidays back in Singapore truly helped in maintaining my identity. Reconnecting with family and working with my mother on dance projects put life back into my breath. During the last three years of my eight-year period abroad, I also started teaching Bharatanatyam at the local temple which provided an avenue for self-expression. This connectivity was vital during my time abroad in maintaining my identity as also discussed in Zontini and Reynolds (2018).

It was never a conscious decision neither do I remember when it exactly happened, but I decided over a period of time that I would be most comfortable embracing myself. I draw from Anthias's (p. 177, 2016) characterization of identity and belonging where identity revolves around the self while belonging is more spatial: spaces and places. Although I struggled with my identity throughout my young adult life, I never recall needing to belong during those eight years spent in Australia. I knew that my time overseas was temporary, to complete my education. I learned to understand and adapt to the Australian culture while continuing to embrace my own culture and identity. The term "acculturation comprehends those phenomena which result when groups of individuals having different cultures come into continuous first-hand contact with subsequent changes in the original culture patterns of either or both groups" (Redfield, Linton, \& Herkovits, 1936, p.149). My return to Singapore was short lived; marriage brought me to a new land.

\section{Coming to America}

Coming to the United States, 6 months after 9/11 was not easy. Fear gripped me as a new immigrant to a country so far away from that tiny yet mighty island I was familiar with. Coming to America was also different as I was older and hopefully, wiser with eight years of migrant experience having lived in Australia. I did not attempt to blend in this time but rather acculturate. However, that did not mean that it was easier to 'settle in'. Reflecting on my transnational migration journey, integration best describes my acculturation (Berry, 1992; 1997). This has been an ongoing balancing act. Once again, my identity was constantly challenged based on various lived experiences. I pursued my $\mathrm{PhD}$ in Social Welfare while continuing to learn, perform and teach Bharatanatyam. The ethnic and cultural diversity of 


\section{On Being and Belonging}

New York City meant that I could travel in the subway in my dance costume and make-up without fear or concern about being discriminated against. On the other hand, I would travel on the subway after class on a Tuesday evening wearing jeans and be told to "go home, you don't belong here". I distinctly remember an incident where the train was stalling between stops and a white male was throwing racist abuses at me. Interestingly, although the subway car was filled with people of multiple ethnicities, nobody said anything. I hoped and prayed that he would just continue yelling and not touch me until I got to the next station, so I could get out of the train and ride the next one. When my husband and I travelled to the midwestern region, where we were received with constant stares at the airport, I proceeded to remove my 'pottu'; a red dot worn by married Hindu women on the center of the forehead. Figuring out what to wear has always been challenging; should I dress in Western or my traditional attire? There were life moments such as during the defense of my dissertation and my $\mathrm{PhD}$ graduation when I felt strongly about wearing a sari (a long cloth draped around the body traditionally worn by South Asian women). It was symbolic for me as it was a representation of my background and generations who came before me. I struggled with my appearance, my attire specifically, when I was job hunting, attending interviews and even when I began working. I would rather wear my ethnic attire over a dress or a skirt. After a couple of years at the University, I have gotten comfortable wearing ethnic clothing at my workplace. Regardless, due to prior experiences, I continue to be mindful of my attire based on my environment. There have been numerous instances of these experiences over the years and my senses in this area have heightened even further in the last couple of years. I love travelling for conferences and yet dread about what to wear. I am always mindful of the state I am travelling to and the conference audience. As an onlooker, one would easily assume that I have integrated quite well but these instances mentioned above have continued to challenge my identity and have become a constant reminder that I don't quite belong. There is extensive research internationally detailing the impact of discrimination, racism and nationalism on one's migration experience, well- being, and sense of belonging (Anthias, 2016; Berry, 1997; Hou, Schellenberg \& Berry, 2018). Like me, migrants struggle to maintain their identity while integrating into their new surroundings. Migrants are unable to establish a sense of belonging when they experience discrimination and are made to feel unwelcome.

Despite these challenges, I have maintained my identity over time. My connection to dance, when I initially moved to America helped immensely as that was the one space in which I could truly express myself. Staying connected to family was also vital. I remember chatting with my mother daily when I initially moved. There would be emails, skype calls, visits home, and visitors from home. Although I missed out on the family life cycle of births, marriages, and deaths, maintaining close ties meant that I never felt detached. My transnational space was built based on my Ceylonese Tamil identity, through the maintenance of my cultural roots and Hindu religion (Anthias, 2016; Blunt, 2007; Faist, 2010). Regardless, this transnational experience has continued to challenge not only my identity but also my sense of belonging and home. My mother would always say "home is where the heart is." This has helped me immeasurably in ensuring that all physical spaces that my family has lived in, has always given us a sense of home. But I have come to realize that it does not mean that it is home.

\section{Motherhood}

Having children, places yet another dimension to this equation. They are American citizens, but they are also of Sri Lankan ethnic background. It has been vital for my husband and me, 
as is the case with other migrant families, to ensure that their offspring are aware of their roots, culture and religion (Friedman, 2011; Zontini \& Reynolds, 2018). Maintaining connection via weekly skype calls with grandparents, and extended family, and visits home have all been part of "Doing Family" (Zontini \& Reynolds, 2018). They attend language classes at our local temple which has connected us to Indian Tamil migrants. We have been able to celebrate religious and cultural festivals with this community over the years. Although this may seem perfect for my children, it is not the same for me, as I encounter similar obstacles as I did in my younger days. There are variations in our spoken language and lifestyle that accentuate my difference within this group. Regardless, I believe that these efforts have strengthened my children's identity and sense of belonging towards our families overseas, ethnic and cultural background and hopefully, ties to the homeland would mean something to them as they grow. Nevertheless, these do not come without challenges. Deepavali (Hindu festival of lights) is typically during a work and school day whilst Christmas is during winter recess. My children started asking for a Christmas tree when they attended preschool. Fear gripped me internally at the thought of celebrating a Christian holiday. I caved in one year as my older son had pneumonia at the during the year end winter break and all he wanted was a Christmas tree over the holidays. I realized that although I wanted them to learn and practice the culture and religion they grew up with, it does not prevent them from enjoying other holidays. Integration is a balancing act but I much rather prefer this to other forms of acculturation.

After all these years though, especially after having children, insecurities around my sense of home and belonging resurfaced. I have always wanted to visit the towns my grandparents grew up in and know my roots. For some reason after all these years, I always felt that I would truly be 'home' and have the sense of being treated the same as everyone else, without any difference when I visit Jaffna, the northeastern part of Sri Lanka.

\section{The Visit}

The time came, and we were able to make the much-anticipated trip to Sri Lanka. This took months of planning by my Appa (father) who made calls to relatives to reconnect after decades. We travelled to Jaffna and after visiting multiple relatives, who provided us with snippets of the past, we were finally seated in my Appa's (father) relative's living room who was going to help us fill the blanks in our diaspora. My Appa proceeded to thank them for hosting us for the afternoon and reconnecting with him. He informed them that he had no interest in reclaiming the land of his father but wanted to know what happened to the family, the home, and land after he left. We were attentive and all ears to listen to stories of my paternal grandfather growing up in the land. But alas, it was not meant to be. In fear of coming to claim his Appa's land, things became sour very quickly. Within 30 minutes, I saw my Appa, the pillar in our family growing up and even today, slouch into the couch in disbelief of what he was hearing. Although my grandfather was unable to make trips back home, he did stay connected, and continuously remitted to repair fences, wells and even the roof of the house. During his time land was partitioned verbally: not legally in writing. All we yearned for was to listen to the stories to help us fill in the blanks. Sitting across the room from us, relatives were more concerned about us making claim to this very land. Informing us of their rights, warning us in a gentle manner that we had no right to claim this land after all these years. What truly unsettled me was when they looked at my brother and me and said that we would never understand or even have any attachment to the land as we were not born or raised on this 


\section{On Being and Belonging}

land. They did not comprehend that although we were not born or raised on the land, we have always had a strong connection from childhood and into our adult lives, of belonging to this place. Although many homes were destroyed during the war, we were told that my grandfather's home still stood. However, we were unable to see it. It was very disappointing, and I will carry this memory to my grave. My perceived sense of homecoming and belonging was shattered to the core after this visit but had no time to immediately process what this meant. I made peace with this visit knowing that we tried. My family gained solace in visiting the temple my maternal grandfather contributed to financially. Growing up, we remembered him remitting money to build this temple in the middle of his hometown. Although this was a highly anticipated trip in helping me gain my sense of belonging and feelings of home, I was reduced to a tourist in my perceived homeland.

Towards the end of this trip, we visited the Kataragamam temple in Katargama, in the south eastern part of the country. My family's home deity is Lord Muruga and both my father and grandfather carry his name. It was important for us to visit this temple that our ancestors always took their pilgrimage to pray. It was also very special as both my parents and my husband's parents were with us as we sat by the river and had our heads shaven to give thanks to the lord (a Hindu ritual). We walked into the temple and interestingly, we observed that prayer was not carried out in the way we are familiar with. The Lord Muruga deity and his vel: a symbol of divinity and wisdom, were not visible in his sanctuary. All we could see was a wall hanging with an embroidery of the god which is unusual in our temples where we would typically be able to see the deity. All I could think about was that I had travelled all this way to pray and could not pray in the way I am accustomed to do so. This was my tipping point, the sheer disappointment that sent me into a renewed spiral of questioning my sense of belonging. Today, many migrants continue to make the journey to their ancestral homeland to maintain their roots and in hopes for their children to establish and maintain these ties. These experiences have been mixed where some migrants have been able to preserve this connectivity, and a sense of belonging while others do not feel that sense of belonging and home anymore (Oeppen, 2013; Marschall, 2017).

\section{Unanswered questions}

It was a couple of months after this trip to Sri Lanka that I started reading the book about the young penguin to my son which resurfaced all these unresolved feelings. Growing up, home was living with my parents. Reflecting on my childhood years, I question if that was home or the land my grandparents grew up in? They spoke of the land as though that was home and where we belonged: not where we lived. My grandparents' narratives were one of happy times. In order to strengthen the ethnic identity across generations, they omitted certain aspects of their hardships. This I learned from my parents, through their stories. Migrants are in constant flux in revision of self along with their memories which impacts their narratives offering insights into cultural and value considerations and a deeper understanding of their position in history (Chamberlain \& Leyesdesdorff, 2004). My grandparents were acutely aware of the impact of their narratives in preserving our Ceylonese Tamil identity and roots. I love the house we grew up in as it was the grand central in my family, and still is even today. Over time, the house has lived through life cycles of various family members including births, coming of age, marriages, and death. It is a house that has truly been lived in. But these stories of the land that once was, kept calling to me. All my life I let myself to believe that I would feel that sense of belonging when I visit the land of my ancestors. Having visited the land, I

Border Crossing 
felt more like an outsider, a tourist. This has left me with unanswered questions. Where is home? Where do I truly belong?

As I maneuver through life, I do not want to just go through the motions of living. I am fortunate to have a beautiful family and am beginning to realize that the concept of home is not about where we live but rather what we do to create a sense of being home. Blunt and Dowling (2006) state that the ideas around home include "the relationships between home and homeland, the existence of multiple homes, diverse home-making practices, and the intersections of home, memory, identity and belonging" (p. 199). In addition to having the above-mentioned memories growing up, continuing to create beautiful memories is also a vital part of this process. I am also realizing that as transnational migrants, the concept of home takes on a more global perspective. Memories are made when we take special trips to visit family in Singapore, Malaysia and Sri Lanka: our multiple homes. My connection to the local migrant Indian community, and involvement with this group along with home-making practices which intersects with my religion, cultural values and ethnic identity contribute towards the diaspora. My identity as a Ceylonese Tamil holds stronger today than it has ever been, but I do continue to struggle with my sense of belonging. There is a disconnect for me as although I am trying to make sense of my experience and feelings around this, I am unable to feel like I belong. The notion of the politics of belonging where Antonsich (2010) argued that 'belonging should be analyzed both as a personal, intimate feeling of being 'at home' in a place (place-belongingness) and as a discursive resource that constructs, claims, justifies, or resists forms of socio-spatial inclusion/exclusion (politics of belonging) (p. 644). I realize that all areas of my lived experiences including discrimination and racism, and the most recent trip to Sri Lanka have contributed to the flux I experience today. I am unable to definitively state a place that I can or ever will be able to call home or have a sense of belonging to.

\section{References}

Anthias, F. (2016). Interconnecting boundaries of identity and belonging and hierarchy-making within transnational mobility studies: Framing inequalities. Current Sociology Monograph, 64(2), 172-190.

Antonsich, M. (2010). Searching for belonging - An analytical framework. Geography Compass, 4(6), 644-659. Blunt, A. \& Dowling, R. (2006). Home. London: Routledge.

Blunt, A. (2007). Cultural geographies of migration: mobility, transnationality and diaspora. Progress in Human Geography, 31(5), 684-694.

Berry, J. W. (1992). Acculturation and adaptation in a new society. International Migration, 30(1), 69-85.

Berry, J. W. (1997). Immigration, acculturation, and adaptation. Applied Psychology: An International Review, 46(1), 5-68.

Berry, J. W. (2013). Research on multiculturalism in Canada. International Journal of Intercultural Relations, 37 , 663-675.

Chamberlain, M. \& Leydesdorff, S. (2004). Transnational families: memories and narratives. Global Networks, 4(3), 227-241.

Faist, T. (2010). Diaspora and transnationalism: What kind of dance partners? In Baubock, R. \& Faist, T. (Eds.), Diaspora and transnationalism (pp. 9-34). Amsterdam University Press.

Friedman, M. (2011). The personal, the political, and the complexity of identity: Some thoughts on Mothering. In Friedman, M \& Schultermandl, S. (Eds.), Growing up transnational. Identity and kinship in a global era (pp.181-189). University of Toronto Press.

Hou, F., Schellenberg, G., \& Berry, J. (2018). Patterns and determinants of immigrants' sense of belonging to Canada and their source country. Ethnic and Racial Studies, 41(9), 1612-1631. 


\section{On Being and Belonging}

Jayasuria De Silva, S. (1999). Portuguese in Sri Lanka: Influence of substratum languages. Journal of the Royal Asiatic Society, 9(2), 251-270.

Marschall, S. (2017). Transnational migrant home visits as identity practice: The case of African migrants in South Africa. Annals of Tourism Research, 63, 140-150.

Noor, N. M. \& Leong, C. H. (2013). Multiculturalism in Malaysia and Singapore: Contesting models. International Journal of Intercultural Relations, 37, 714-726.

Oppen, C. (2013). A stranger at 'home': interactions between transnational return visits and integration for Afghan-American professionals. Global Networks, 13(2), 261-278.

Redfield, R., Linton, R., \& Herskovits, M. (1936). Memorandum on the study of acculturation. American Anthropologist, 38, 149-152.

Tan, S. E. (2004). Ethnic relations in Singapore: Evidence from survey data. In Suryadinata, L. (Ed.), Ethnic relations and nation-building in Southeast Asia: The case of the ethnic Chinese. Singapore: Southeast Asian Studies.

Wilson, K. (2008). Where is home little pip? Margaret K. McElderry Books.

United Nations Migration, International Organization for Migration (2020). World Migration Report 2020. Retrieved from https://www.un.org/sites/un2.un.org/files/wmr_2020.pdf

Zontini, E. \& Reynolds, T. (2018). Mapping the role of 'transnational family habitus' in the lives of young people and children. Global Networks, 18(3), 418-436. 